\title{
Human Papillomavirus 6 Antibody Measurement
}

National Cancer Institute

\section{Source}

National Cancer Institute. Human Papillomavirus 6 Antibody Measurement. NCI

Thesaurus. Code C127621.

The determination of the amount of human papillomavirus 6 antiboy present in a sample. 